\title{
Turkey and Latin America: A New Horizon for a Strategic Relationship
}

\author{
Lic. Ariel GONZÁLEZ LEVAGGI*
}

\section{Abstract}

After the impact of the economic and financial crisis of 2008-2009, Latin America and the Caribbean began to grow again 4.3\% in 2011 and $3.0 \%$ in 2012, which totalize a GDP of US $\$ 5.6$ trillion. One of the main factors for economic growth in the region has been the trade sector. Between 2004 and 2010 both the export and import of goods doubled while the percentage of total external debt to GDP decreased more than one third. In this context, Latin America is seen by Turkey as a land of opportunities to expand trade, build global alliances and find new investment alternatives for its focus on strategic projection in new markets. A stable trade policy towards Latin America and the Caribbean, starting with its "Promoting Trade Strategy with Latin American Countries" in 2006 and the expansion of the commerce, has positioned Turkey as an emerging trade partner in the last geographical frontier of Turkish foreign policy.

\section{Key Words}

Latin America, Turkey, foreign policy, trade partnership, diplomacy.

* Executive Director, Argentine Center of International Studies (CAEI) Secretary, Eurasian Department, Institute of International Relations, National University of La Plata.

\section{Latin America and the World Economy}

After the impact of the economic and financial crisis of 2008-2009, Latin America and the Caribbean began to grow again in 2011 at a rate exceeding $4.3 \%$. One of the main factors of economic growth in the region has been the export sector. Between 2004 and 2010, both the import and export of goods doubled ${ }^{1}$ while the percentage of total external debt to GDP decreased from $34.3 \%$ to $19.7 \% .^{2}$

In the first decade of the $21^{\text {st }}$ century, Latin America and the Caribbean (LAC) performed well. Between 2003 and 2010 , its economy grew $33 \%$ at constant 2005 US\$ prices, and $154 \%$ at current US $\$$ prices. $^{3}$ The average growth rate during the last eight years exceeded 5\%. At present LAC represents about $8 \%$ of the world economy, whereas a century ago it was only $4.4 \% .{ }^{4}$ The GDP of LAC countries combined totalize US \$5.6 trillion, ${ }^{5}$ surpassing countries such as France and Germany. In terms of GDP 
per capita, LAC stands out because it is composed of mostly middle income countries. ${ }^{6}$ In 2010, per capita income surpassed US \$11,000 (adjusted for purchasing power parity). Yet, despite the steady growth in per capita income, the region is still far from the USA or average European country.

An essential element for the economic growth after 2000 has been the incorporation of all the economic wisdom that had accumulated after a series of economic crises that the region experienced during the 1980s and the 1990s.

Another important indicator of the region's economic growth has been the progress in international trade. Exports grew from US $\$ 392$ to US $\$ 888$ billion between 2003 and 2010, while imports grew from US $\$ 353$ to US $\$ 843$ billion. The increase in merchandise exports is due to several reasons, among which are the improvement in terms of trade, an increase in LAC's productive capacity, especially in the area of primary goods and low-tech manufactured goods, the increase in external demand (especially from China, India and other developing Asian countries) and the relative increase in the prices of the region's typical exports.

However, in foreign trade it is also important to distinguish the structures of Mexico and Caribbean countries, which are closely linked to the USA, from the South American countries that have a more diversified series of partners in East and Southeast Asia, as well as in alternative regions, such as the Maghreb and the Middle East. 
Figure 1: Latin America and the Caribbean: Total exports according to destination, 2006-2011 (in million US dollars)

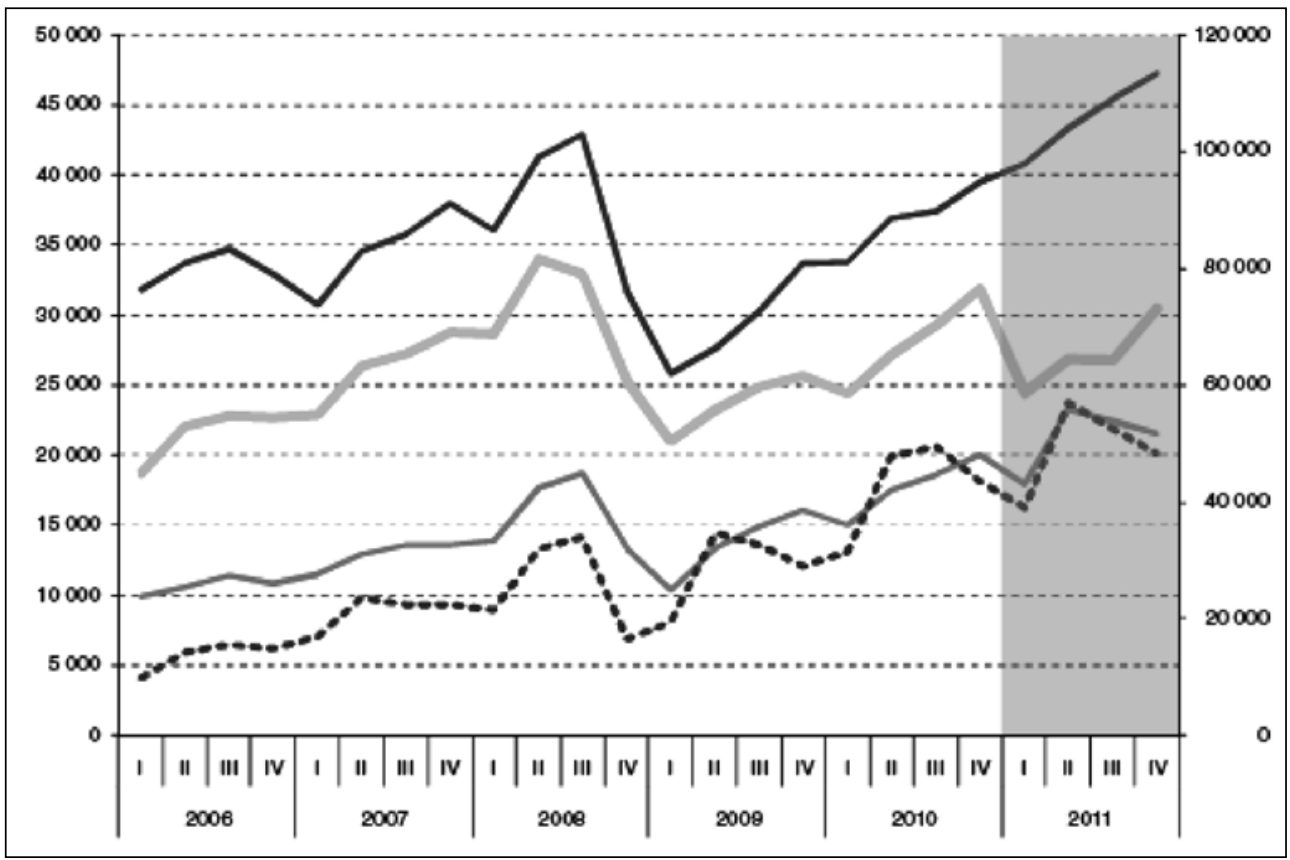

European Union

Other Asian countries

China

USA

Source: CEPAL, Statistical Yearbook for Latin America and the Caribbean 2011, Economic Commission for Latin America and the Caribbean, Santiago de Chile, 2011, p. 33.

An essential element for the economic growth after 2000 has been the incorporation of all the economic wisdom that had accumulated after a series of economic crises that the region experienced during the 1980 s and the 1990s. Since then, an important point has been the relative weight of external debt in national budgets. The level of public debt was reduced from $80 \%$ of public budgets in 1990 to $30 \%$ in 2010 , thanks to the implementation of fiscal reforms and proper macroeconomic management of state revenues and expenditures. $^{7}$

The economic crisis of 2008-2009 partially affected LAC. Although the region was affected by the fall of global prices of raw materials, a reduction in the flow of remittances and a rationing 
of international financing sources due to the instability of financial capital markets, ${ }^{8}$ it was able to recover rapidly. Only in 2009 there was a negative performance, a year in which several countries suffered economic recession. One of the key reasons for the recovery has been the implementation of countercyclical measures oriented towards internal demand and the promotion of the export sector.

The creation of the Community of Latin America and the Caribbean States (CELAC) has generated a road of reverse engineering to join the different integration processes at the regional level, such as the UNASUR (Union of South American Nations), the MERCOSUR (Common Market of the South), the Andean Community and the CARICOM (Caribbean Community). The potential to reach a common LAC position is a recurrent subject in the cooperation agenda at a regional level, since LAC as a region is the third largest energy supplier and the largest producer of foodstuffs in the world.

The international economic context in the last couple of years accelerated participation with the emerging regions, as well as the development of SouthSouth commerce. From this perspective, the G20 is a critical platform for global cooperation where the emerging economies could have an increasingly important role. The presence of Argentina, Brazil and Mexico as representatives of the region allows for coordination and establishes bridges of experiences with such emerging powers as Turkey, Indonesia and the rest of the BRICS. ${ }^{9}$

\section{Turkey's New Foreign Policy towards New Global Spaces}

From 1991 to the present, Turkey has presented itself as a relatively autonomous ally of NATO. The diversification of Turkish foreign policy has been one of the main elements behind this change. This growing autonomy from the West and diversification in its international agenda beyond military matters has been a slow process, and certainly not without difficulties. During the Cold War, NATO was the dominant determinant of foreign policy, generating an internationally 'securitised' agenda that gave precedence to defence and security over economic development and political democratisation.

As part of the 'European' segment of its foreign policy agenda, Turkey has been assimilating multiple political and economic reforms in order to join the European Union as a full member, and has been trying to reinforce its identity 
as a democratic country. The 'freezing' of membership negotiations in December 2006 impacted heavily on Turkey's international agenda. Since 2007, with the political strengthening of the JDP- as well as its leaders, Prime Minister Recep Tayyip Erdoğan and President Abdullah Gül- strategic priorities underwent a paradigm change that was called by several experts the "New Turkish Foreign Policy". ${ }^{10}$

Turkey has proposed that its behaviour at a regional and global level will not be a zero-sum game, but instead will be a positive-sum game through increasing interaction, commerce and exchange with its immediate region.

However, this new Turkish foreign policy is far from being an abstract notion; this development has been part of Turkish society's answer to a series of factors. Among the most important external factors is the progressive loss of US hegemony, which has transformed the unipolar system towards multipolarity, in which emerging countries have a more important role. The formation of the G20, an organisation of variable geometry, and the establishment of
IBSA $^{11}$ are examples of this. In short, during the first decade of the $21^{\text {st }}$ century, Turkish foreign policy had the goal of increasing its importance in neighbouring regions, as well as on a global scale.

At the regional level, recurrent instability in the Middle East has required an actor with the diplomatic capacity to reach agreements that are not imposed by extra-regional actors. The decade-long American presence in Iraq and Afghanistan has made it very difficult to establish stability in the region. The JDP has improved Turkey's relations in its regional and global environment through multiple actions, such as the Alliance of Civilisations initiative, in which it works with Spain, the attempt to mediate between Syria and Israel and the Brazil-Iran-Turkey tripartite agreement on nuclear fuel swap, among others. At the domestic level, Turkey has transformed its pluralist political system into a dominant party system, thanks to the combination of economic growth with a proper political leadership.

Of all these elements, the global and regional factors have played the most important role in the paradigm shift, especially after 2007 . The stagnation of Turkish-European relations, the changing political panorama in the Middle East and the growing tension between energy 
suppliers in its neighbourhood have pushed for an even deeper change. ${ }^{12}$ In this new foreign policy era, Turkey has proposed that its behaviour at a regional and global level will not be a zero-sum game, but instead will be a positive-sum game through increasing interaction, commerce and exchange with its immediate region. Moreover, it has also displayed a relatively autonomous foreign policy towards the West, after decades of very close relations.

From an ideological/identity point of view, the present international vision of the JDP is structured upon the geopolitical doctrine of "Strategic Depth", which was developed by Professor Ahmet Davutoğlu, the Minister of Foreign Affairs since 2009. Davutoğlu holds that Turkey is a "central country", contrary to the notion of a "frontier country" in the middle of a vast terrestrial Afro-Euroasiatic land mass. In terms of its sphere of influence, Turkey is a country with simultaneous interests in the Middle East, the Balkans, the Caucasus, Central Asia, the Caspian basin, the Mediterranean, the Black Sea and the Gulf. Such centrality requires that the past as a "peripheral country" is left behind, and proposes a new position, one that allows for the generation of security and stability for Turkey as well as for its regional partners. ${ }^{13}$
According to Davutoğlu, the new foreign policy has been guided from its beginning by five principles: i) a balance between security and democracy at the domestic level; ii) "zero problems" towards Turkey's neighbours; ${ }^{14}$ iii) the development of relations with neighbouring regions and distant geographical spaces; iv) the adherence to a multi-dimensional foreign policy which has complementary- not competitive- relations with other global actors; and finally v) an increase its global importance by developing deep bilateral and multilateral relations in the framework of "rhythmic diplomacy". ${ }^{15}$

Turkey's centralist concept has identified Latin America and the Caribbean as one of the global spaces of interest for its claim as an emerging power in the $21^{\text {st }}$ century.

The re-shaping of Turkish international identity besides the modifications in the international and regional scenario has generated a visible change in Turkey's foreign policy, differentiating it from certain European policies carried out during the first term of the JDP. Since 2007, Turkey has reinforced its presence in the Middle East, tried to establish a new status quo with Armenia, functioned 
as mediator between Occidental nations and Iran and strengthened its role as an energy conduit between Central Asia and Europe.

Turkey has modified its guiding paradigm and subtly changed the course of its foreign policy without changing its main axis. ${ }^{16}$ There has been no break with Turkey's traditional partners but Turkey's agenda has become more complex and turned, despite its limitations, global. Turkey saw in the international game of the BRICS an example, and a chance, to have a more active role in international affairs.

Its Middle East policy has been the most revealing practice of the new Turkish foreign policy and it reflects the ideological orientation of the JDP and its need for commercial expansion in the region. ${ }^{17}$ The Erdoğan government approached the Palestinian party Hamas, contributed to the stabilisation of the new Iraq and presented itself as an example of Islamic democracy for the Arab Spring. The focus has not been solely directed towards the Middle East. The JDP government has tried to expand its focus and participation to other regions of the world by establishing economic associations and developing multiple instances of political cooperation.

The economic factor has been the most important: Turkey's impressive growth rate of $5 \%$ per year between 2003 and 2010 and the competence of its industrial sector have been major incentives for the search of new markets. Turkey's economic and commercial flexibility has allowed the country to re-orient its economy and compete at a global scale. The search for foreign markets has been quite successful since it almost quadrupled its export volume in that period, with main destinations being Germany, Iraq, the United Kingdom, the USA and France. Comparing 2011 with 2010, the markets that expanded the most were Malta (124\%), Hong Kong (75\%), Slovenia (74\%), South Korea (69\%), Morocco (49\%), Brazil (46\%) and Ukraine (38\%). ${ }^{18}$

Within the framework of Turkey being a 'centralist' country, its new foreign policy towards three qualitatively different spaces can be identified as a) Occidental, b) regional and c) global. The first space corresponds to the classical orientation of Turkish foreign policy in that the US, the European Union, and NATO are important for its international security, commerce and foreign investments. The second space represents the expansion of the new foreign policy defined by Davutoğlu: the Middle East, the Balkans, the Caucasus, Central Asia, the Caspian basin, the Mediterranean, the Black Sea and the Gulf. Lastly, the global space incorporates 
Sub-Saharan Africa, Oceania, South and East Asia and Latin America.

\section{Turkey's Latin American} Agenda: A Strategic Perspective

From the independence of Latin American nations to the present, the interaction between Latin America and Turkey has been characterized by its low intensity. However, in the last 15 years mutual ties have multiplied, generating several expectations regarding the future of relations. Whereas some analysts see the enlargement of such relations as a reflection of the "over extension" of Turkish foreign policy, ${ }^{19}$ others argue that Turkey's political, economic and strategic growth during the last few years that has generated a process of global expansion, which includes Latin America, as well as Sub-Saharan Africa.

Geographical distance has been the main difficulty hampering the relationship between Latin America and Turkey. However, there were other less visible problems, such as those of language, scarcity of contacts and the lack of a foreign policy initiative from Turkey towards Latin America and vice-versa. Similarly, a shortage of direct flights, successive economic crises, commercial protectionism and the scarcity of embassies to carry out diverse types of contacts could also be mentioned.

The three foundational steps of present Turkish foreign policy towards Latin America include the following: the official visit of President Süleyman Demirel to Argentina, Brazil and Chile in 1995, the success of the "Action Plan for Latin America and the Caribbean" in 1998 and the declaration of the "Year of Latin America and the Caribbean" in 2006.

President Demirel's visit in April 1995 was the first official visit to Latin America by a Turkish head of state, and is an important visit in terms of the development of stronger relations. It is important to note that only in that year eight bilateral agreements were signed. Whereas his visit to Brazil opened a channel of permanent consultation between the two countries, his visit to Argentina was useful in balancing the lobbying activities of Armenian diaspora in Argentina. Demirel's visit also followed the visit of Argentinean President Carlos Menem to Turkey in 1992. In Chile, Demirel signed an Agreement of Cultural Cooperation and a Memorandum of Understanding on the Protection of Investments, which are still in force.

The Action Plan for America Latina and the Caribbean accelerated the 
development of relations.$^{20}$ Its main goals were to complete the legal framework of bilateral relations, to encourage the political dialogue at a high level, to increase the level of the economic and commercial relations through the participation of private sector, to improve intra-regional dynamics by becoming a permanent observer in regional organisations and to increase the awareness of contemporary Turkey in LAC region.

Some of the actions taken as a consequence of this plan include the signing of several cooperation agreements in different areas, an increase of highlevel contacts and the establishment of bilateral mechanisms of political consultation with Argentina, Bolivia, Brazil, Chile, Costa Rica, Cuba, Mexico and Peru. Other concrete steps towards mutual collaboration include the restoration of parliamentary friendship groups, establishing bilateral "business councils", participation in commercial exhibitions in LAC, the creation of joint economic committees and the incorporation of Turkey as an observer in regional cooperation mechanisms such as the Caribbean Community (CARICOM) and the Organisation of American States (OAS) ${ }^{21}$ In short, during this period mutual relations improved in political as well as commercial areas.
Even though Turkey's 2001 economic crisis briefly interrupted these developments, commerce resumed its growth, quadrupling between 2001 and 2006. Up to that point, Latin America had a secondary role, and did not enjoy much visibility in the future planning of the Turkish Ministry of Foreign Affairs (MFA). In 2006 came the third landmark action, the Government of Turkey declared 2006 as the "Year of Latin America and the Caribbean". This action prompted the representatives of different ministries to give new impetus to the "Action Plan for Latin America and the Caribbean".

Since 2007, Turkey's new foreign policy has cultivated a multidimensional perspective in a global and interdependent world. In this framework, Turkey's centralist concept has identified Latin America and the Caribbean as one of the global spaces of interest for its claim as an emerging power in the $21^{\text {st }}$ century.

Turkey hasfollowed an active diplomacy by stressing its agenda in an international system that is increasingly becoming multipolar. A clear example of this policy has been the successful expansion towards Africa, which has subsequently worked as a "mirror example" of Turkey's immersion in the LAC region. ${ }^{22}$ The Turkish government saw Latin America together with Sub-Saharan Africa as an 
opportunity to reach out and globally expand its interests. On the other hand, even though Latin American countries have different interests in their bilateral 'meetings' with Turkey, there has also been an underlying need for enlarging the political and commercial horizon to new partners that would then help achieve a globally expanded margin of action.

Considering the growing weight of Latin America in the multilateral commercial and political spheres, the global expansion of Turkish interests would be incomplete, especially if we take into account the role of Brazil and Mexico in the last few years. Since 2006, the foundations of foreign policy towards the Latin American region have been based on high-level mutual visits, commercial development and multiple cultural and educational activities promoted by the 1998 plan. ${ }^{23}$

\section{Bilateral and multilateral dimensions}

Between 2009 and 2011, the quantity of contacts and activities accelerated, thanks to the active diplomacy of the JDP and the expansion of foreign policies priorities of the LAC countries, generating a series of visits at the highest level. Turkish Prime Minister Erdoğan visited Mexico in 2009 and Brazil and Chile in May 2010. Argentinean President Cristina Fernandez de Kirchner visited Turkey in January 2011 during her visit to the Middle East, which included Kuwait and Qatar, while Lula da Silva (president of Brazil between 2003 and 2011) visited Turkey in 2009 and Dilma Rousseff, current president of Brazil, in October 2011. Moreover, the visits of President of Costa Rica Oscar Arias in November 2009 and President of Colombia Juan Manuel Santos in November 2011 were also important.

Brazil is Turkey's most important partner in Latin America. Prime Minister Erdoğan attended the Third Forum of the Alliance of Civilizations in May 2010, around the time when the tripartite agreement between Iran-BrazilTurkey on nuclear swap was signed.

During that visit, the heads of governments signed the "Action Plan for Strategic Association" based on eight cooperation points: bilateral and multilateral political dialogue, commerce and investment, energy, biodiversity and environment, defence, security, science and technology and lastly education and culture. The links between Brazil and Turkey were secured with a series of meetings that began with the visit of Celso Amorim, Brazil's foreign minister since 2004. 
During his visit in May 2009, President Lula da Silva attended multiple events, including the "Turkish Brazilian Economic Forum" and the opening of the "Centre of Latin American Studies" at Ankara University. Improved bilateral relationsled to the establishment of a highlevel cooperation committee between Turkey and Brazil in 2006, a mechanism Turkey uses with other important actors, such as Russia, Greece and Spain, among others, for diplomacy. Finally, there was the visit of President Dilma Rousseff in October 2011, when she signed with President Gül the "Strategic Perspective of a Dynamic Association TurkeyBrazil” joint declaration and bilateral cooperation agreements on matters of higher education and justice.

Another framework of political cooperation and dialogue has been the formation of parliamentary friendship groups with Turkey in Argentina, Brazil, Venezuela, Chile, Mexico, Cuba, Costa Rica, Uruguay, Jamaica, Colombia and Panama. In the case of Mexico, on 6 April 2010, the Friendship Group MexicoTurkey was created to improve bilateral ties from a parliamentary scope and to make it into a vehicle of permanent dialogue on subjects common to both nations.

Turkey also has a special interest in multilateral cooperation, particularly in the United Nations, G20 and different international organisations within Latin America. In the first case, the region is an important asset given the weight, together with African countries, in the UN General Assembly. Even though Turkey does not take part in the G77 plus China or the Movement of the Non-Aligned Countries, and it forms part of the "Western European and Others Group" (WEOG) within the United Nations, the support of Latin American countries has been important, for example in its election as a nonpermanent member of the UN Security Council for the period 2009-2010.

In the case of the G20, ${ }^{24}$ Argentina, Brazil and Mexico are members of its emerging countries group together with Turkey. The G20 is of critical importance, for it symbolises the change in international economic power from developed countries towards the emerging ones, which have been the protagonists of economic growth in the last decade. Neither Latin American countries nor Turkey are unaware of this reality. Issues ranging from international financial regulation proposals to the solution of the Greek debt problem, and the criticisms of protectionism, have all been included in their bilateral and multilateral talks.

Turkey has also been interested in the regional organisations in LAC and has become observers in the Organisation of 
American States (OAS) ${ }^{25}$ the Association of Caribbean Estates (ACE), the MERCOSUR, the Rio Group and the Caribbean Community (CARICOM). Regarding the MERCOSUR, aside from its observer status, in 2008 Turkey also signed the "Framework Agreement to Establish a Free Commerce Area Between the MERCOSUR and the Republic of Turkey". In December 2010, the "Memorandum for the Establishment of a Dialogue of Political Meeting and Cooperation" between the MERCOSUR parties and Turkey was signed.

Finally, Turkey participates in several common platforms alongside Latin American countries. First, it forms part of the G33, whose aim is to try to get developing countries to have a limited opening of their agricultural markets. ${ }^{26}$ Likewise, it is part of a group of Friends of the Anti-dumping Negotiations (ANA/FAN5) together with Brazil, Chile, Colombia, Costa Rica and Mexico, which tries to improve the use of the anti-dumping measures. ${ }^{27}$ Turkey is also among the sponsors of the document "W 52" on intellectual property (ADPIC), together with Brazil, Colombia and Peru, among others.

In the political arena, it is safe to say that a foundation has been established that can generate sustainable policies in the long term. However, the problem is that there is much less interest in Latin America towards Turkey. Multiple barriers at the geographical and cultural levels have created important setbacks. Until recently, examples of change in cultural and academic areas were scarce, making rapprochement beyond political matters rather difficult. Strategies to generate cultural bridges in the field of languages, art or history could construct greater interdependence.

\section{Trade policy and foreign direct investment}

In recent years, both Turkey and Latin America have been seen as important markets for export expansion. The multiplication of mutual contacts and commercial missions in the last few years has taken place alongside a quantitative growth in commerce between the parties.

Turkey's foreign trade has seen exponential development in the last few years. Exports grew from US \$36 billion in 2002, to US $\$ 125$ billion in 2011 , whereas imports rose to US $\$ 220$, billion in 2010 from US $\$ 51$ billion in 2003, according to the Turkish Institute of Statistics. Even though Turkey's main commercial partners are the USA (10\%) and the EU (42\%), primarily such countries as Germany, Italy, France and the UK, the growing importance of 
Russia (8\%), China (7\%) and Middle East countries (13.5\%) can also be seen.

Only a decade ago, Turkey's interest in the western hemisphere was focused solely on relations with the US. During the last few years, with its market diversification framework, Turkey has become progressively more interested in the LAC region, despite the fact that in 2000 the region counted for less than $1 \%$ of its total commerce. ${ }^{28}$ Even though at the moment LAC has a secondary role, its profile has been growing thanks to the establishment and implementation of the "Turkey's Commercial Development Strategy towards the Americas". In 2010, the share of commerce with LAC reached $2 \%$ of Turkey's total commerce.

Among the recommended measures of the Commercial Development Strategy, there are reciprocity agreements on protection and promotion of investments; agreements on taxes and double taxation; meetings of bilateral economic commissions; cooperation agreements in technical areas such as agriculture, navigation, air transport, tourism, customs and health; participation in Latin American business fairs and establishing business councils; the organisation of commercial missions to the region; and finally, cooperation in the fields of consulting and construction. The main objective was to increase exports to US $\$ 3$ or US $\$ 4$ billion in five years, and secure a sustainable presence in the region, including by getting contracts for services and investments. ${ }^{29}$ Even though the quantitative objective was not achieved as in 2012 Turkish exports exceeded US $\$ 2,9$ billion, there was still a considerable increase in Turkey's commercial presence in the region. When compared to the records in 2000, exports grew by more than $900 \%$, which is a significant figure (see Table 1).

Table 1: Turkish-Latin American
Commerce
of US \$)

\begin{tabular}{|l|l|l|l|}
\hline & $\begin{array}{l}\text { Turkey's } \\
\text { exports }\end{array}$ & $\begin{array}{l}\text { Turkey's } \\
\text { imports }\end{array}$ & Total \\
\hline 2000 & 261 & 624 & 885 \\
\hline 2001 & 369 & 448 & 817 \\
\hline 2002 & 310 & 642 & 952 \\
\hline 2003 & 288 & 1,178 & 1,466 \\
\hline 2004 & 516 & 1,478 & 1,993 \\
\hline 2005 & 638 & 2,031 & 2,668 \\
\hline 2006 & 719 & 2,465 & 3,184 \\
\hline 2007 & 979 & 3,106 & 4,085 \\
\hline 2008 & 1,575 & 3,782 & 5,358 \\
\hline 2009 & 1,020 & 2,736 & 3,756 \\
\hline 2010 & 1,836 & 3,564 & 5,400 \\
\hline 2011 & 2,285 & 4,973 & 7,256 \\
\hline 2012 & 2,962 & 5,149 & 8,111 \\
\hline
\end{tabular}

Source: Turkish Ministry of Economy 
Another characteristic of the strategy was the identification of six key countries: Argentina, Brazil, Chile, Cuba, Mexico and Venezuela. In South America, exports to these select countries showed impressive progress in the 20062011 period. They doubled in the case of Venezuela, quadrupled in Argentina and Chile, and increased by seven fold for Brazil. On the other hand, imports showed a minor change since countries in Latin America, particularly Brazil and Argentina, saw massive increases in their exports to Turkey. Brazil doubled its exports to Turkey from US \$934 million to US $\$ 1,948$ million, followed by Argentina from US $\$ 300$ million to US $\$ 470$ million.

Commercial relations between Turkey and the LAC region are high in comparison to other spheres, and they have experienced a rapid pace of growth.

Except from the imports coming from Argentina and Brazil, most imports from the LAC are primary goods and natural resources, while most of Turkey's exports to the LAC are manufactured goods with low to medium technology. The main Turkish export products to Latin America are car parts and engines, iron and steel, material for nuclear reactors, fruits and edible goods and textiles and synthetic fibres. Imports from the LAC region to Turkey include copper, fuels, minerals and oil, along with machinery and electrical equipment.

An important consequence of Turkey's strategy towards the Americas has been the search for preferential commercial or free trade agreements with the countries of the region. In particular, Chile and Colombia have strongly subscribed to this agenda, for their development model is based on trade liberalisation as well.

In 2004, during the visit of Chilean President Ricardo Lagos to Turkey, Turkish President Ahmet Necdet Sezer officially initiated free trade agreement (FTA) talks between the two countries. In July 2009, Turkey's Minister of Foreign Trade and Chile's Minister of Foreign Relations signed the FTA, which took effect on 1 March 2011. The FTA allows for $96 \%$ of the commerce between the parties to be duty free, and for the reduction of the remaining within six years. Thanks to this agreement, Turkey has better conditions to compete in the Chilean market, especially in products such as cars, machinery, appliances and food, among others.

Based on the Commercial Cooperation Agreement signed in 2006, Colombia and Turkey started FTA negotiations 
in May 2011. Colombia has identified Turkey as one of its main partners in its trade negotiations agenda that was approved by the Superior Council of Foreign Commerce. Moreover, both Colombia and Turkey are members to the upcoming CIVETS $^{30}$ club. The negotiation for the FTA is in its final phase, and it is likely that a final agreement will be reached.

The search for market diversification on the part of Turkey and the LAC countries, cooperation in international forums and changes in Turkey's foreign policy identity have also played a role in the recent rapprochement.

Unfortunately, investments have not been the strongest point in bilateral relations. They remain limited in scale, and are among the issues that are still causing delays in the relations. For instance Turkish investments in Colombia barely surpassed US $\$ 500,000$ between 2007 and 2010, and most of that was in the real estate sector.

However, there are forthcoming investments, among which are the announcements of Biota Laboratories plan to invest US $\$ 10$ million in the cosmetics market (distributed between Argentina, Colombia, Dominican Republic, El Salvador, Panama and Paraguay). Similarly, PETROBRAS (Petroleo de Brazil) announced joint energy investments with TPAO in the BlackSea, andTPAO withECOPETROL (Empresa Colombiana de Petroleo) in the Gonzalez Bock, near Cucuta City. In Argentina, there is currently one Turkish Company (Kordsa), part of the Sabanci Group, and its investments are around US $\$ 35$ million. There are opportunities for expansion in Argentina, depending on the dynamism of the economies and the will to undertake future investments.

In sum, commercial relations between Turkey and the LAC region are high in comparison to other spheres, and they have experienced a rapid pace of growth. There have been adequate policy initiatives that have supplemented the growth in foreign trade. On the other hand, investments remain at a sub optimal level at best.

\section{Conclusion}

In the last few years the deepening of relations between the LAC region and Turkey seems to have been the consequence of systemic factorsparticularly the erosion of the North American hegemony and the ascendance of emerging powers. Secondly, the 
search for market diversification on the part of Turkey and the LAC countries, cooperation in international forums and changes in Turkey's foreign policy identity have also played a role in the recent rapprochement. Latin America and the Caribbean have become new frontiers for Turkish diplomacy.

These coming years will illustrate the consequences of Turkey's presence in the LAC region, and will demonstrate whether this was a momentary development, or if they were the basis for sustainable longterm relations.

Economic dynamism, as well as the growing prominence of LAC in international forums- especially in the case of Brazil- has increased the enthusiasm to intensify bilateral relations in the future. This has been a major motivation in Turkey's foreign policy towards LAC.

Even though there is a promising horizon of cooperation between both parties, relations are far from being completely satisfactory. There are series of issues that still require significant attention, such as cooperation on development, academic and cultural cooperation and migration, among others.

Turkey has taken its new foreign policy with a global outlook to its last frontier, Latin America and the Caribbean. These coming years will illustrate the consequences of Turkey's presence in the LAC region, and will demonstrate whether this was a momentary development, or if they were the basis for sustainable long-term relations. 


\section{Endnotes}

1 CEPAL, Statistical Yearbook for Latin America and the Caribbean 2011, Economic Commission For Latin America and the Caribbean, Santiago de Chile, 2011, pp. 115-116.

2 Ibid., p. 124.

3 Ibid., pp. 79-81.

4 Angus Maddison, The World Economy, OECD Publishing, 2006, p. 641.

5 Ibid., p. 81.

6 Claudio M. Loser and Drew Arnold, "América Latina 2040: Una Agenda Para Un Futuro de Prosperidad Compartida", in Carlos Malamud, Federico Steinberg and Concha Tejedor (eds.), Anuario Iberoamericano 2011, Real Instituto Elcano/EFE, Madrid, pp. 48-49.

7 OCDE/CEPAL, Perspectivas Económicas de América Latina 2011. Transformación del Estado para el Desarrollo, OECD Publishing, 2011, p. 15.

8 Organization of American States, Informe de Politicas: La Crisis Económica Global; Efectos y Estrategias Politicas, Fifth Summit of the Americas, p. 4.

9 The acronym of Brazil, Russia, India and China created by the investment agency Goldman Sachs as the emerging powers of the $21^{\text {st }}$ century. From 2006, the BRICs start a series of multilateral meetings. In 2010, South Africa entered the group formally; hence they are now the BRICS.

10 Mehmet Özkan and Birol Akgün, “Turkey's Opening to Africa”, Journal of Modern African Studies, Vol. 48, No. 4 (2010), p. 528.

11 An inter-regional group formed by India, Brazil and South Africa to approach positions in multiple fields of their multilateral agenda.

12 Ziya Meral and Jonathan Paris, "A Paradigm Shift in Turkish Foreign Policy-Transition and Challenges", The Washington Quarterly, Vol. 33, No. 4 (2010), p. 78.

13 Ahmet Davutoğlu, “Turkey's Foreign Policy Vision: An Assessment of 2007”, Insight Turkey, Vol. 10, No. 1 (2008), p. 79.

14 The principle of "zero problems with the neighbours" has served to secure its internal front so as to extend its influence in the region, though in 2011 this was subject to multiple pressures by the "overflow" of the "Arab Spring" on Syria and the increase in the Kurdish problem given the multiple terrorist attacks of the Kurdistan Workers Party (PKK). Analysts such as Joshua Keating or Svante Cornell argue that a series of important problems has given relative importance to this principle.

15 The concept of "rhythmic diplomacy" is a theme that indicates a simultaneity in the growing and development of bilateral and multilateral relations vide Davutoğlu, "Turkey's Foreign Policy Vision", pp. 79-83.

16 Ziya Öniş, "Multiple Faces of the "New" Turkish Foreign Policy: Underlying Dynamics and a Critique", Insight Turkey, Vol. 13, No. 1 (2011), p. 53. 
17 Bülent Aras, “Turkey's Rise in the Greater Middle East: Peace-building in the Periphery", Journal of Balkan and Near Eastern Studies, Vol.11, No.1 (2009), p. 21.

18 "İhracat 134.5 Milyar Dolarla Tarihi Rekor Kırdı, 'Milyar Dolar Ligi'ne 15 İl Yerleşti”, Hürriyet, 3 January 2012.

19 Gareth Jenkins, “Turkey-Latin America Relations”, at http:/www.worldpoliticsreview.com/ trend-lines/7445/global-insider-turkey-latin-america-relations [last visited 1 October 2013].

20 Ayşe Çelenk, “Türkiye’nin Latin Amerika Politikasi 2010”, in Burhanettin Duran, Kemal İnat and Mesut Özcan (eds.), Türk Dış Politikası Yıllı̆̆ı 2010, Ankara, Siyaset, Ekonomi ve Toplum Araştırmaları Vakfı (SETA), 2011, pp. 485-501.

21 Luz María de la Mora, Las Relaciones de America Latina y el Caribe con el Medio Oriente: Situación actual y áreas de oportunidad, Caracas, SELA, 2011, p. 20.

22 Süleyman Şensoy, "First Workshop Final Report 'the Relations Between Turkey - Latin America and Caribbean”, at http://www.tasam.org/en/Icerik/3283/first_workshop_final_ report_quotthe_relations_between_turkey_-_latin_america_and_caribbeanquot [last visited 1 September 2013].

23 Çelenk, “Turkiye’nin Latin Amerika Politikase 2010”, pp. 485-501.

24 This multilateral institution has existed since 1999 and was strengthened because of the international financial crisis of 2008/2009. It includes Germany, Canada, the USA, France, Italy, Japan, The United Kingdom, Russia, Saudi Arabia, Argentina, Australia, Brazil, China, South Korea, India, Indonesia, Mexico, South Africa and Turkey.

25 Ten of the 65 countries that have observer status are from the Middle East (Saudi Arabia, Algeria, Egypt, Israel, Lebanon, Morocco, Qatar, Tunis, Turkey and Yemen), which allows them to be better informed of the subjects on LAC. This has strengthened the political dialogue between the parties and has increased opportunities in the South-South cooperation cfr, De la Mora, Las relaciones de America Latina y el Caribe con el Medio Oriente, SELA, 2011, p. 42.

26 This group also includes some regional countries as Antigua and Barbuda, Barbados, Belize, Bolivia, Cuba, Dominica, the Dominican Republic, El Salvador, Granada, Guatemala, Guyana, Haiti, Honduras, Jamaica, Nicaragua, Panama, Peru, Saint Kitts and Nevis, Santa Lucia, San Vicente and Las Granadinas, Surinam, Trinidad and Tobago and Venezuela.

27 De la Mora, Las relaciones de América Latina y el Caribe con el Medio Oriente, p. 28.

28 John Daly, “Turkey Seeks to Increase Trade with Latin America”, Eurasia Daily Monitor, Vol. 5, No. 77 (2008).

29 Dış Ticaret Müsteşarlığı, “Turkey’s Trade Development Strategy Towards the Americas”, 2006, p. 5.

30 CIVETS is an acronym created by Robert Ward of the Economist Intelligence Unit (EIU) to identify emerging countries that have projections of high growth in the next few decades and could succeed the BRIC. The countries include Colombia, Indonesia, Vietnam, Egypt, Turkey and South Africa. 